Phosphorus Research Bulletin Vol. 12 (2001), 65-72

\title{
SYNTHESES OF $\mathrm{N}-(\omega$-HYDROXYALKYL)TRIPHOSPHORAMIDATES BY INORGANIC CYCLO-TRIPHOSPHATE
}

\author{
HIDEKO INOUE, HIROKAZU NAKAYAMA, and \\ MITSUTOMO TSUHAKO* \\ Department of Functional Molecular Chemistry, Kobe Pharmaceutical \\ University, Kobe 658 - 8558, Japan.
}

\begin{abstract}
The phosphorylation of amino alcohols has been achieved using inorganic sodium cyclo-triphosphate hexahydrate, $\mathrm{Na}_{3} \mathrm{P}_{3} \mathrm{O}_{9} \cdot 6 \mathrm{H}_{2} \mathrm{O}$, in aqueous solution. The main phosphorylated products were imidotriphosphates of amino alcohols as evidenced by ${ }^{1} \mathrm{H},{ }^{13} \mathrm{C}$, and ${ }^{31} \mathrm{P}$ NMR spectra. In the phosphorylation of 3-amino-1-propanol (3A1P), 4-amino-1-butanol (4A1B), and 5-amino-1-pentanol (5A1P), only their amino groups were phosphorylated to give imidotriphosphates, with their maximum yields of more than $97 \%$.
\end{abstract}

\section{INTRODUCTION}

Sodium cyclo-triphosphate hexahydrate, $\mathrm{Na}_{3} \mathrm{P}_{3} \mathrm{O}_{9} \cdot 6 \mathrm{H}_{2} \mathrm{O}\left(\mathrm{P}_{3 \mathrm{~m}}\right)$, which is a simple inorganic condensed phosphate having a six-membered ring, is a very attractive phosphorylating agent for synthesizing biologically important organic phosphorus compounds in one step in aqueous solution. The previous works indicated that the phosphorylation products of alkylamines ${ }^{1}$ and alkyldiamine ${ }^{2}$ with $\mathrm{P}_{3 \mathrm{~m}}$ are alkylamidoand alkylimidotriphosphates with $\mathrm{P}-\mathrm{N}$ bond.

On the other hand, $\beta$-D-glucose and other monosaccharides are also phosphorylated with $\mathrm{P}_{3 \mathrm{~m}}$ to form $\beta$-D-aldose 1-triphosphate with $\mathrm{P}-\mathrm{O}$ bond ${ }^{3-5}$. In this study the phosphorylation of amino alcohols, which have both $\mathrm{OH}$ and $\mathrm{NH}_{2}$ groups, was examined in detail.

Received May 16, 2001; Accepted July 26, 2001 


\section{RESULTS AND DISCUSSION}

Amino alcohols examined in the present study are shown in Chart 1. The phosphorylation was carried out essentially according to the previous method $^{3}$. Figure 1 shows HPLC profiles for the reaction mixture of 3-amino-1-propanol (3A1P) (2.5 $\left.\mathrm{mol} \cdot \mathrm{L}^{-1}\right)$ and $\mathrm{P}_{3 \mathrm{~m}}\left(0.5 \mathrm{~mol} \cdot \mathrm{L}^{-1}\right)$ incubated at room temperature and $\mathrm{pH} 12$. A peak of the main phosphorylated product (1) appeared at the retention

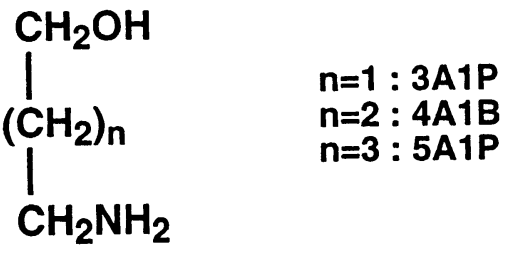

CHART 1 time of about $20 \mathrm{~min}$, predicting that the product (1) is a triphosphate derivative of 3A1P. Another chromatographic peak was assigned to starting material $\mathrm{P}_{3 \mathrm{~m}}$.

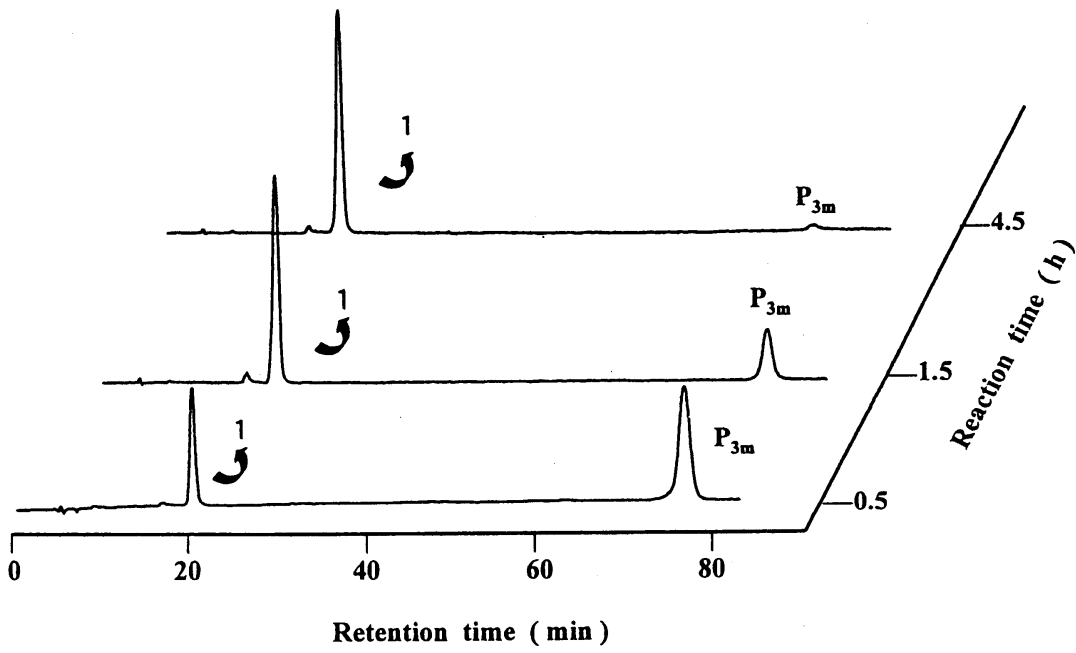

FIGURE 1 HPLC profiles for the reaction mixture of 3A1P and $\mathrm{P}_{3 \mathrm{~m}}$. 3A1P : $\mathrm{P}_{3 \mathrm{~m}}=2.5 \mathrm{~mol} \cdot \mathrm{L}^{-1}: 0.5 \mathrm{~mol} \cdot \mathrm{L}^{-1}, \mathrm{pH} 12$, and room temperature. $1 ;$ product

Figure 2 shows the change in the amounts of the product (1) at 3A1P $(2.5 \mathrm{~mol} \cdot$ $\left.\mathrm{L}^{-1}\right)$ and $\mathrm{P}_{3 \mathrm{~m}}\left(0.5 \mathrm{~mol} \cdot \mathrm{L}^{-1}\right), \mathrm{pH} 12$, and room temperature. The amount of $\mathbf{1}$ increased with the reaction time, reaching about $98 \%$ after $6.5 \mathrm{~h}$. The yield remained constant after $15 \mathrm{~d}$ without hydrolysis of imidotriphosphate. Table 1 summarizes the yields of the product 1 under various reaction conditions. The phosphorylation by $\mathrm{P}_{3 \mathrm{~m}}$ 
proceeded completely with the condition of the molar ratio of 3A1P $: \mathrm{P}_{3 \mathrm{~m}}=5: 1$ or higher. Considering a reaction time, the recommended condition for phosphorylation of amino alcohols is 3A1P : $\mathrm{P}_{3 \mathrm{~m}}=5: 1, \mathrm{pH} 12$, and room temperature.

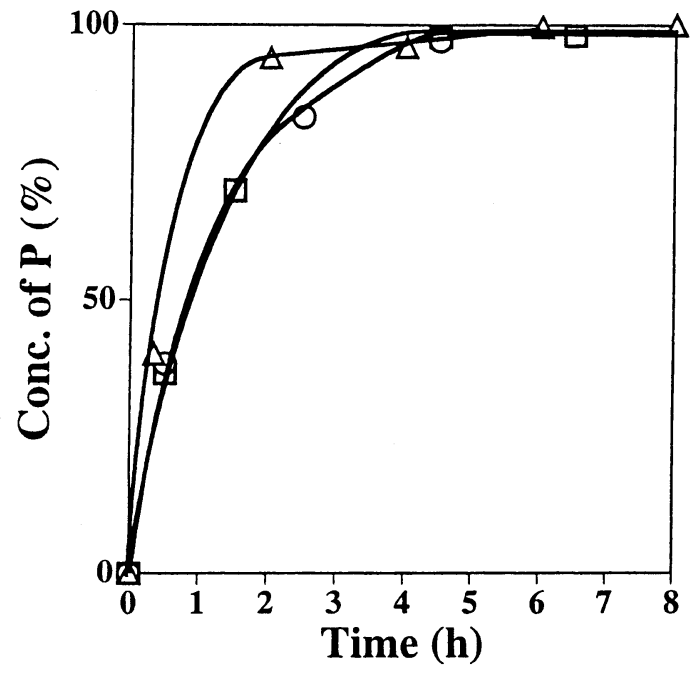

FIGURE 2 Changes in the amounts of the products in the reaction of 3A1P $(\square)$, 4A1B $(\bigcirc), 5 \mathrm{A1P}(\triangle)\left(2.5 \mathrm{~mol} \cdot \mathrm{L}^{-1}\right)$ and $\mathrm{P}_{3 \mathrm{~m}}\left(0.5 \mathrm{~mol} \cdot \mathrm{L}^{-1}\right)$ at $\mathrm{pH} 12$ and room temperature.

TABLE 1 Yields of the phosphorylation products

\begin{tabular}{cccc}
\hline \multicolumn{2}{c}{ Reaction conditions } & \multirow{2}{*}{ Yield (\%) } \\
\cline { 1 - 2 } Mixing ratio & $\mathrm{pH}$ & Time (h) & \\
\hline 3A1P : $\mathrm{P}_{3 \mathrm{~m}}$ & 12 & 1.5 & 99 \\
$10: 1(5.0 \mathrm{M}: 0.5 \mathrm{M})$ & 10 & 24 & 99 \\
& 7 & 6.5 & 14 \\
$5: 1(2.5 \mathrm{M}: 0.5 \mathrm{M})$ & 12 & 6.5 & 98 \\
$1: 1(0.5 \mathrm{M}: 0.5 \mathrm{M})$ & 12 & 48 & 76 \\
4A1B $: \mathrm{P}_{3 \mathrm{~m}}$ & & & 98 \\
$5: 1(2.5 \mathrm{M}: 0.5 \mathrm{M})$ & 12 & 4.5 & 100 \\
5A1P $: \mathrm{P}_{3 \mathrm{~m}}$ & & 8 & \\
$5: 1(2.5 \mathrm{M}: 0.5 \mathrm{M})$ & 12 & & \\
\hline
\end{tabular}


To identify $1,{ }^{31} \mathrm{P},{ }^{1} \mathrm{H}$ and ${ }^{13} \mathrm{C}$ NMR spectra were measured. Figure $3(\mathrm{~A})$ shows the ${ }^{31} \mathrm{P}$ NMR spectrum of the product 1 . The spectrum showed one doublet of doublet of doublets at $0.44 \mathrm{ppm}$, which became doublet on ${ }^{1} \mathrm{H}$-decoupling, indicating the characteristic peak of $\mathrm{P}_{\alpha}$ in triphosphate derivative of 3A1P. $\mathrm{P}_{\alpha}$ signal at around 0 ppm is characteristic in alkylamido- and alkylimidotriphosphates with P-N bond ${ }^{2,6,7}$. Therefore, the product $\mathbf{1}$ is forecasted to be triphosphoramidate with P-N bond.

Figure 3(B) shows ${ }^{1} \mathrm{H}$ NMR spectrum. The doublet of doublet of doublets at 2.95 ppm was assigned to $\mathrm{H}-3$ of 1 . The ${ }^{3} J_{\mathrm{P}_{\alpha} \mathrm{H}-3}$ value of 1 is $9.6 \mathrm{~Hz}$, which is consistent with that deduced from ${ }^{31} \mathrm{P}$ NMR.

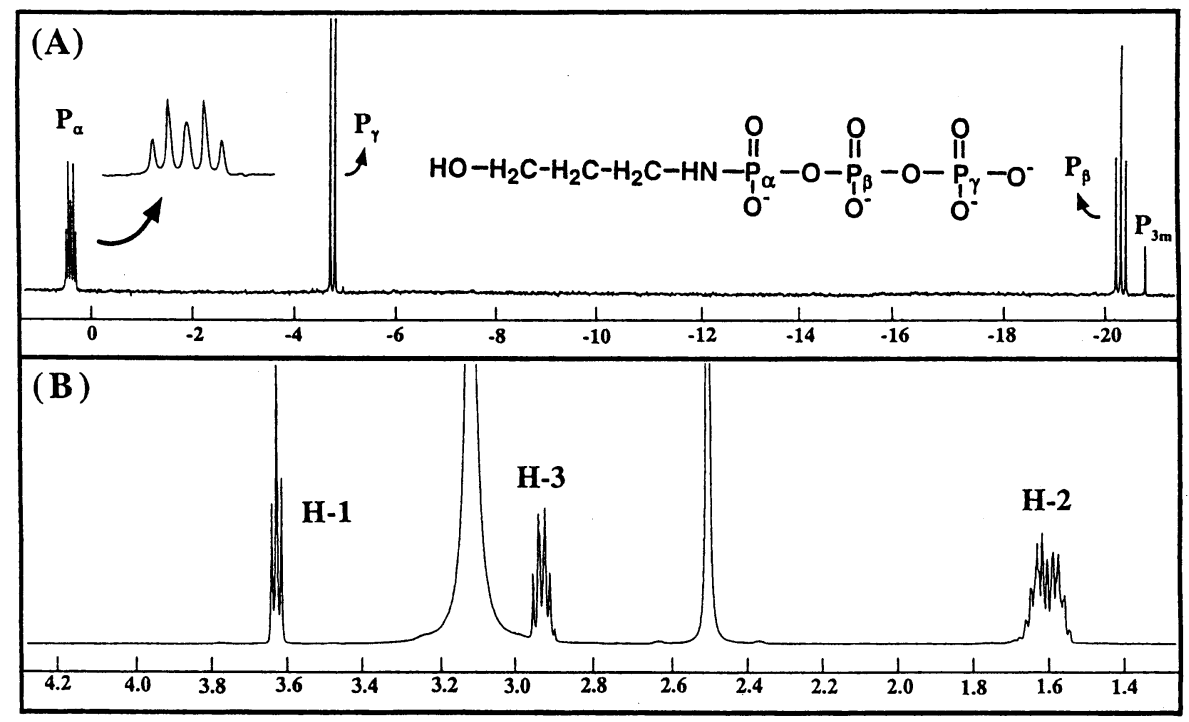

FIGURE $3 \quad{ }^{31} \mathrm{P}$ NMR spectrum (A) and ${ }^{1} \mathrm{H}$ NMR spectrum (B) of product 1. The signals at 2.5 and $3.1 \mathrm{ppm}$ in (B) are due to EDTA.

Furthermore, the ${ }^{31} \mathrm{P}-{ }^{1} \mathrm{H} 2 \mathrm{D}-\mathrm{NMR}$ (heteronuclear multiple bond correlation spectroscopy (HMBC)) experiment also showed a correlation of $\mathrm{P}_{\alpha}$ at $0.44 \mathrm{ppm}$ and the H-3 signal at $2.95 \mathrm{ppm}$. Therefore, the phosphorylated product (1) in the reaction of 3A1P with $\mathrm{P}_{3 \mathrm{~m}}$ was proved to be $\mathrm{N}$-(3-hydroxypropyl)triphosphoramidate.

The reaction of 4-amino-1-butanol (4A1B) or 5-amino-1-pentanol (5A1P) with 
$\mathrm{P}_{3 \mathrm{~m}}$ was carried out under the same reaction conditions as the case of 3A1P. The results of HPLC indicated that the products $\mathbf{2}$ and $\mathbf{3}$ are the triphosphate derivatives of 4A1B and 5A1P, respectively. The yields of 2 and 3 increased with the reaction time and maximum yields were 97.7 and $100 \%$, respectively (Fig. 2 and Table 1).

${ }^{31} \mathrm{P},{ }^{1} \mathrm{H}$ and ${ }^{13} \mathrm{C}$ NMR spectra of 2 and 3 suggest them to be imidotriphosphates ${ }^{6,7}$. Therefore, 4A1B and 5A1P are phosphorylated with $\mathrm{P}_{3 \mathrm{~m}}$ to form $\quad \mathrm{N}$-(4-hydroxybutyl)triphosphoramidate (2) and $\mathrm{N}$-(5hydroxypentyl)triphosphoramidate (3). The phosphorylation of 4A1B and 5A1P with $\mathrm{P}_{3 \mathrm{~m}}$ proceeds by the same mechanism as that of 3A1P (Scheme 1).
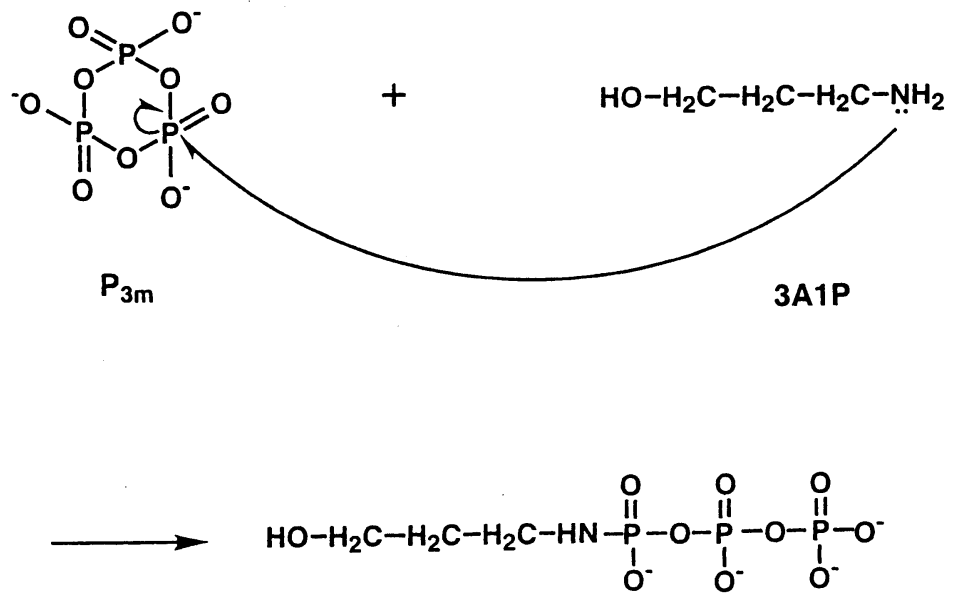

$N$-(3-hydroxypropyl)triphosphoramidate

\section{SCHEME 1}

The selective phosphorylation of 3A1P, 4A1B, and 5A1P with $\mathrm{P}_{3 \mathrm{~m}}$ will be explained by the following mechanism. At $\mathrm{pH} 12, \mathrm{P}_{3 \mathrm{~m}}$ is easily attacked by nucleophilic reagents such as amine ${ }^{1,2}$, alcohol ${ }^{8}$, amino acid $^{7,9}$, and nucleoside ${ }^{10}$. In the present study, thus, the lone electron pair on the amino group of 3A1P nucleophilically attacks a phosphorus atom on $\mathrm{P}_{3 \mathrm{~m}}$ to open its six-membered ring. No attack by the hydroxyl group of amino alcohol will be due to low degree of dissociation of the proton. Therefore, the phosphorylated products in the reactions of 3A1P, 4A1B, and 5A1P with $\mathrm{P}_{3 \mathrm{~m}} \quad$ were proved to be $N$-(3-hydroxypropyl)triphosphoramidate, $N$-(4- 
hydroxybutyl)triphosphoramidate, and $\quad N$-(5-hydroxypentyl)triphosphoramidate, respectively.

\section{EXPERIMENTAL}

Materials and Methods Sodium cyclo-triphosphate, $\mathrm{Na}_{3} \mathrm{P}_{3} \mathrm{O}_{9} \cdot 6 \mathrm{H}_{2} \mathrm{O}$ $\left(\mathrm{P}_{3 \mathrm{~m}}\right)$, was prepared as described in a previous paper'. 3-Amino-1-propanol (3A1P) was purchased from Wako Chemical Industries, Ltd. 4-Amino-1-butanol (4A1B) and 5-amino-1-pentanol (5A1P) were purchased from Tokyo Kasei. Sodium 2,2-dimethy2-silapentane-5-sulfonate (DSS) were purchased from Sigma (St. Louis, USA). ${ }^{13} \mathrm{C}$ NMR spectra with broad band ${ }^{1} \mathrm{H}$-decoupling and ${ }^{1} \mathrm{H}$ NMR spectra were measured with Varian Gemini 300 and 200 spectrometers. Samples were dissolved in $\mathrm{D}_{2} \mathrm{O}(99.9 \%)$ to avoid the effect of ${ }^{1} \mathrm{H}$ in water. DSS was used as an external standard for ${ }^{13} \mathrm{C}$ and ${ }^{1} \mathrm{H}$ NMR spectra. ${ }^{31} \mathrm{P}$ NMR spectra with and without broad band ${ }^{1} \mathrm{H}$-decoupling and ${ }^{31} \mathrm{P}-{ }^{1} \mathrm{H} 2 \mathrm{D}$ HMBC spectra were obtained with a Varian VXR-500 spectrometer using $85 \% \mathrm{H}_{3} \mathrm{PO}_{4}$ as an external standard. For ${ }^{1} \mathrm{H},{ }^{13} \mathrm{C}$, and ${ }^{31} \mathrm{P}$ NMR measurements products ( 1 - 3) obtained as barium salts were dissolved in 3\% EDTA solution.

HPLC analysis was carried out with a JASCO GULLIVER HPLC system (Tokyo, Japan), coupled with a JASCO DU-4F flow injection system to detect phosphate by a post-column reaction. A column $(150 \times 6.0 \mathrm{~mm}$ i.d.) packed with a polystyrene-based anion-exchanger (TSK gel, SAX, $5 \mu \mathrm{m}$, TOSOH, Japan), was used for the analysis of phosphate. The column temperature was maintained at $40^{\circ} \mathrm{C}$. A convex gradient elution technique using 0.2 and $0.45 \mathrm{~mol} \cdot \mathrm{L}^{-1}$ potassium chloride solutions was employed for the analysis of phosphate. Determination of phosphorus was carried out by spectrophotometry of a phosphorus-molybdenum heteropoly blue complex at $830 \mathrm{~nm}$. The flow rate of the eluent was $1.0 \mathrm{~mL} \cdot \mathrm{min}^{-1}$.

The Procedure for the Syntheses of $1-3$ The reaction of amino alcohols $\left(0.5-5.0 \mathrm{~mol} \cdot \mathrm{L}^{-1}\right)$ with $\mathrm{P}_{3 \mathrm{~m}}\left(0.5 \mathrm{~mol} \cdot \mathrm{L}^{-1}\right)$ was carried out at $\mathrm{pH} 12$ by adding $6 \mathrm{~mol} \cdot \mathrm{L}^{-1}$ sodium hydroxide solution and room temperature. After the reaction of $1 \mathrm{~d}$, $25 \mathrm{~mL}$ of $1 \mathrm{~mol} \cdot \mathrm{L}^{-1} \mathrm{BaCl}_{2}$ aqueous solution was added to $50 \mathrm{~mL}$ of the reaction solution, the products $\mathbf{1}-\mathbf{3}$ precipitated out. They were separated from the solution, then washed thoroughly with distilled water to obtain crystalline barium salts. 
Barium $N$-(3-hydroxypropyl)triphosphoramidate (1) : ${ }^{1} \mathrm{H}$ NMR $\left(\mathrm{D}_{2} \mathrm{O}\right) \delta: 3.65$ $\left(2 \mathrm{H}, \mathrm{dd}, J_{1,2}=6.5 \mathrm{~Hz}, \mathrm{H}-1\right), 1.71\left(2 \mathrm{H}\right.$, dddd, $\left.J_{1,2}=6.5 \mathrm{~Hz}, J_{2,3}=6.8 \mathrm{~Hz}, \mathrm{H}-2\right), 2.95(2 \mathrm{H}$, ddd, $\left.J_{2,3}=6.8 \mathrm{~Hz}, J_{\mathrm{P}_{\alpha} \mathrm{H}-3}=9.6 \mathrm{~Hz}, \mathrm{H}-3\right) .{ }^{13} \mathrm{C} \mathrm{NMR}\left(\mathrm{D}_{2} \mathrm{O}\right) \delta: 62.1(1 \mathrm{C}, \mathrm{s}, \mathrm{C}-1), 35.8(1 \mathrm{C}$, d, $\left.J_{\mathrm{P}_{\alpha} \mathrm{C}-2}=9.2 \mathrm{~Hz}, \mathrm{C}-2\right), 41.0(1 \mathrm{C}, \mathrm{s}, \mathrm{C}-3) . \quad{ }^{31} \mathrm{P} \mathrm{NMR}\left(\mathrm{D}_{2} \mathrm{O}\right) \delta: 0.44\left(1 \mathrm{P}, \mathrm{ddd}, J_{\mathrm{P}_{\alpha} \mathrm{P}_{\beta}}=20.8\right.$ $\left.\mathrm{Hz}, J_{\mathrm{P}_{\alpha} \mathrm{H}-3}=9.6 \mathrm{~Hz}, \mathrm{P}_{\alpha}\right),-20.2\left(1 \mathrm{P}, \mathrm{dd},{J_{\mathrm{P}^{\mathrm{P}}}}_{\beta}=20.8 \mathrm{~Hz},{J_{\mathrm{P}} \mathrm{P}_{\gamma}}_{\gamma}=19.4 \mathrm{~Hz}, \mathrm{P}_{\beta}\right),-4.7(1 \mathrm{P}, \mathrm{d}$, $\left.J_{\mathrm{P}_{\beta}{ }{ }_{\gamma}}=19.4 \mathrm{~Hz}, \mathrm{P}_{\gamma}\right)$. Anal. Calcd for $\mathrm{C}_{3} \mathrm{H}_{7} \mathrm{O}_{10} \mathrm{NP}_{3} \mathrm{Ba}_{2} \cdot 2 \mathrm{H}_{2} \mathrm{O}: \mathrm{C}, 58.1 ; \mathrm{N}, 22.6 ; \mathrm{P}, 149.7$; Ba, 442.45. Found: C, 58; N, 22; P, 149; Ba, 434.

Barium $N$-(4-hydroxybutyl)triphosphoramidate (2) : ${ }^{1} \mathrm{H}$ NMR $\left(\mathrm{D}_{2} \mathrm{O}\right) \quad \delta: 3.59$ $\left(2 \mathrm{H}, \mathrm{dd}, J_{1,2}=6.5 \mathrm{~Hz}, \mathrm{H}-1\right), 1.56\left(2 \mathrm{H}, \mathrm{dddd}, J_{1,2}=6.5 \mathrm{~Hz}, J_{2,3}=7.2 \mathrm{~Hz}, \mathrm{H}-2\right), 1.51(2 \mathrm{H}$, dddd, $\left.J_{2,3}=7.2 \mathrm{~Hz}, J_{3,4}=7.1 \mathrm{~Hz}, \mathrm{H}-3\right), 2.88 \quad\left(2 \mathrm{H}, \mathrm{ddd}, J_{3,4}=7.1 \mathrm{~Hz}, J_{\mathrm{P}_{\alpha} \mathrm{H}-4}=9.2 \mathrm{~Hz}, \mathrm{H}-4\right)$. ${ }^{13} \mathrm{C}$ NMR $\left(\mathrm{D}_{2} \mathrm{O}\right) \delta: 64.2(1 \mathrm{C}, \mathrm{s}, \mathrm{C}-1), 31.5(1 \mathrm{C}, \mathrm{s}, \mathrm{C}-2), 29.9\left(1 \mathrm{C}, \mathrm{d}, J_{\mathrm{P}_{\alpha} \mathrm{C}-3}=9.0 \mathrm{~Hz}, \mathrm{C}-3\right)$, 44.0 (1C, s, C-4). ${ }^{31} \mathrm{P} \mathrm{NMR}\left(\mathrm{D}_{2} \mathrm{O}\right) \delta: 0.64$ (1P, ddd, $J_{\mathrm{P}_{\alpha} \mathrm{P}_{\beta}}=20.2 \mathrm{~Hz}, J_{\mathrm{P}_{\alpha} \mathrm{H}-4}=9.2 \mathrm{~Hz}, \mathrm{P}_{\alpha}$ ), - $20.0\left(1 \mathrm{P}, \mathrm{dd}, J_{\mathrm{P}_{\alpha} \mathrm{P}_{\beta}}=20.2 \mathrm{~Hz}, J_{\mathrm{P}_{\beta} \mathrm{P}_{\gamma}}=19.6 \mathrm{~Hz}, \mathrm{P}_{\beta}\right),-4.7\left(1 \mathrm{P}, \mathrm{d}, J_{\mathrm{P}_{\beta} \mathrm{P}_{\gamma}}=19.6 \mathrm{~Hz}, \mathrm{P}_{\gamma}\right)$. Anal. Calcd for $\mathrm{C}_{4} \mathrm{H}_{9} \mathrm{O}_{10} \mathrm{NP}_{3} \mathrm{Ba}_{2} \cdot 3 \mathrm{H}_{2} \mathrm{O}: \mathrm{C}, 73.6 ; \mathrm{N}, 21.5 ; \mathrm{P}, 142.4 ; \mathrm{Ba}$, 420.7. Found: $\mathrm{C}$, 73; N, 21; P, 143; Ba, 417.

Barium $N$-(5-hydroxypentyl)triphosphoramidate (3) : ${ }^{1} \mathrm{H}$ NMR $\left(\mathrm{D}_{2} \mathrm{O}\right) \delta: 3.56$ $\left(2 \mathrm{H}, \mathrm{dd}, J_{1,2}=6.5 \mathrm{~Hz}, \mathrm{H}-1\right), 1.52\left(2 \mathrm{H}, \mathrm{dddd}, J_{1,2}=6.5 \mathrm{~Hz}, J_{2,3}=7.0 \mathrm{~Hz}, \mathrm{H}-2\right), 1.34(2 \mathrm{H}$, dddd, $J_{2,3}=7.0 \mathrm{~Hz}, J_{3,4}=7.5 \mathrm{~Hz}, \mathrm{H}-3$ ), 1.47 (2H, dddd, $J_{3,4}=7.5 \mathrm{~Hz}, J_{4,5}=7.5 \mathrm{~Hz}, \mathrm{H}-4$ ), $2.85\left(2 \mathrm{H}\right.$, ddd, $\left.J_{4,5}=7.5 \mathrm{~Hz}, J_{\mathrm{P}_{\alpha} \mathrm{H}-5}=9.0 \mathrm{~Hz}, \mathrm{H}-5\right) .{ }^{13} \mathrm{C} \mathrm{NMR}\left(\mathrm{D}_{2} \mathrm{O}\right) \delta: 64.4(1 \mathrm{C}, \mathrm{s}, \mathrm{C}-1)$, $33.7(1 \mathrm{C}, \mathrm{s}, \mathrm{C}-2), 25.1(1 \mathrm{C}, \mathrm{s}, \mathrm{C}-3), 33.2\left(1 \mathrm{C}, \mathrm{d}, J_{\mathrm{P}_{\alpha} \mathrm{C}-4}=9.2 \mathrm{~Hz}, \mathrm{C}-4\right), 44.2(1 \mathrm{C}, \mathrm{s}, \mathrm{C}-5)$. ${ }^{31} \mathrm{P}$ NMR $\left(\mathrm{D}_{2} \mathrm{O}\right) \delta: 0.74\left(1 \mathrm{P}\right.$, ddd, $\left.J_{\mathrm{P}_{\alpha} \mathrm{P}_{\beta}}=20.2 \mathrm{~Hz}, J_{\mathrm{P}_{\alpha} \mathrm{H}-5}=9.0 \mathrm{~Hz}, \mathrm{P}_{\alpha}\right),-20.2(1 \mathrm{P}, \mathrm{dd}$, $\left.J_{\mathrm{P}_{\alpha} \mathrm{P}_{\beta}}=20.2 \mathrm{~Hz}, J_{\mathrm{P}_{\beta} \mathrm{P}_{\gamma}}=19.6 \mathrm{~Hz}, \mathrm{P}_{\beta}\right),-4.7\left(1 \mathrm{P}, \mathrm{d}, J_{\mathrm{P}_{\beta} \mathrm{P}_{\gamma}}=19.6 \mathrm{~Hz}, \mathrm{P}_{\gamma}\right)$. Anal. Calcd for $\mathrm{C}_{5} \mathrm{H}_{12} \mathrm{O}_{10} \mathrm{NP}_{3} \mathrm{Ba}_{2} \cdot 5 \mathrm{H}_{2} \mathrm{O}: \mathrm{C}, 88.1 ; \mathrm{N}, 20.6 ; \mathrm{P}, 136.3 ; \mathrm{Ba}, 402.8$. Found: C, 87; N, 20; P, 138; $\mathrm{Ba}, 381$. 
ACKNOWLEDGEMENTS The authors thank assistant professor M. Sugiura of Kobe Pharmaceutical University for the measurements of ${ }^{31} \mathrm{P}$ and ${ }^{31} \mathrm{P}-{ }^{1} \mathrm{H} 2 \mathrm{D}$ (HMBC) NMR spectra.

\section{REFERENCES}

1 W. Feldmann, E. Thilo, Z. Anorg. Allg. Chem., 327, 159 (1964).

2 M. Tsuhako, A. Nakahama, S. Ohashi, H. Nariai, and I. Motooka, Bull. Chem. Soc. Jpn., 트, 1372 (1983).

3 H. Inoue, M. Watanabe, H. Nakayama, and M. Tsuhako, Chem. Pharm. Bull., $\underline{46}, 681$ (1998).

4 H. Inoue, H. Nakayama, and M. Tsuhako, Carbohydr. Res., 324, 10 (2000).

5 H. Inoue, M. Watanabe, H. Nakayama, and M. Tsuhako, Chem. Pharm. Bull., $\underline{48}, 802$ (2000).

6 M. Tsuhako, C. Sueyoshi, T. Miyajima, S. Ohashi, H. Nariai, and I. Motooka, Bull. Chem. Soc. Jpn., 59, 3091 (1986).

7 H. Inoue, Y. Baba, T. Furukawa, Y. Maeda, and M. Tsuhako, Chem. Pharm. Bull., 41, 1895 (1993).

8 W. Feldmann, Chem. Ber., 100,3850 (1967).

9 M. Tsuhako, N. Fujita, A. Nakahama, T. Matsuo, M. Kobayashi, and S. Ohashi, Bull. Chem. Soc. Jpn., 53, 1968 (1980).

10 M. Tsuhako, M. Fujimoto, S. Ohashi, H. Nariai, and I. Motooka, Bull. Chem. Soc. Jpn., 57, 3274 (1984). 